\title{
Adsorption of Malachite Green by Jordanian Diatomite Ores: Equilibrium Study
}

\section{Emad El Qada}

Chemical Engineering Department, Mu'tah University, Karak, Jordan

\begin{abstract}
The focal theme of this work is to assess the ability of Jordanian diatomite to treat MG-bearing effluents. Effects of several experimental parameters namely, particle size of diatomite, $\mathrm{pH}$ and initial $\mathrm{MG}$ concentration were investigated through liquid-phase adsorption processes. Several equilibrium isotherm models were applied. It was found that initial MG concentration, $\mathrm{pH}$ and particle size of diatomite had a significant effect on the adsorption process. MG uptake has increased from $99.3 \mathrm{mg} / \mathrm{dm}^{3}$ to $898.7 \mathrm{mg} / \mathrm{dm}^{3}$ over the whole concentration range. A high percentage of MG removal $(99.6 \%)$ was achieved as the diatomite particle size decreased from $500-710 \mu \mathrm{m}$ to $125-250 \mu \mathrm{m}$. The optimum pH for the removal of MG was=9. Freundlich model was satisfactorily applied to the experimental data.
\end{abstract}

Keywords: Adsorption, Equilibrium isotherm, Malachite green, Diatomite, Wastewater Treatment.

\section{Introduction}

Malachite green (MG) is a cationic triphenylmethane dye that forms positively charged colored molecules when dissolved in water (Litefti et al., 2017). Many industries, including textile, cotton, pulp, leather, food and wool, are using MG for coloring (Al-Wahbi, 2018). It is also used as an antifungal, antiseptic and antiprotozoan agent in aquacultures and animal husbandry (Oktay et al., 2016; Heydaria and Khavarpour, 2018). Thus, such industries are considered as a major source of MG dye in water bodies (Lee et al., 2018). Today MG is receiving much more attention due to its adverse effects on human beings as well as on aquatic ecosystems. Several researchers have reported several health hazards associated with the use of MG (Yang et al., 2017; Pan and Zhang, 2009; Roja et al., 2017). However, MG is still detected in foodstuff, fish and animal milk, due to illegal use (Pan and Zhang, 2009). MG is recognized as a stable dye with low biodegradability which makes the natural decolorization of its effluents a difficult process. Thus, the discharges of MG-bearing effluents into the water bodies represent a serious threat to aquatic life. Hence, treatment of such effluents before its final disposal to the aquatic environment is very important (Litefti et al., 2017). Several technologies classified as chemical, biological and physical processes have been assessed for the remediation of wastewater contaminated with dyes such as flotation, ozonation, filtration, chemical oxidation, coagulation, aerobic and anaerobic microbial degradation, etc. However, none of these conventional methods has the necessities required for the successful treatment process: high efficiency and low capital cost (Lee et al., 2018). Ali et al. (2018) asserted that most of the remediation technologies currently available are expensive and non-ecofriendly. Chowdhury and Saha (2013) announced that these methods pose techno-economical limitations for field-scale applications. In addition, the complex chemical structure of dyes enables them to resist fading with time and on exposure to sunlight, water, soap and many chemicals. Therefore, conventional wastewater treatment processes may not be the suitable choice for treating dyes effluents (Oktay et al., 2016). One of the most economical, attractive, reliable and effective decolourization process is adsorption (Oktay et al., 2016). It is not only a promising physicochemical technique for removing colour from wastewater, but it also offers the best potential for a wide range of pollutants removal. Moreover, it shows superiority comparing to the other treatment processes because of its low initial cost, sludge-free operation, simplicity of design, ease of operation, recovery of the sorbate, insensitivity to toxic substances, low energy demand and high quality of the treated effluent (Oktay et al., 2016; Heydaria and Khavarpour, 2018; Ali et al., 2018). Since the efficiency of the adsorption technology mainly depends on the cost and removal capacity of adsorbents used (Litefti et al., 2017), it is of crucial important to seek for an eminent material to be used in the adsorption process. Many investigators have focused on innovation of low cost, commercially abundant and eco-friendly adsorbent with superior adsorption capacity. Currently, diverse attractive natural adsorbents have been examined for their efficient use as adsorbents for removing dyes from wastewater such as bentonite (Blanco-Flores et al., 2016), wood apple shell (Sartape et al., 2017), algal biomass (Gajare and Menghani, 2012), Chinese diatomite (Tian et al., 2016), and clay (Dhahir et al., 2013).

Received on September 2, 2019; accepted on November 16, 2019 Correspondence concerning this article should be addressed to Emad. El Qada (E-mail address: e anadele@yahoo.com ORCiD ID of Emad El Qada https https://orcid.org/0000-0002-3364-8618. 
Diatomite earth also known as diatomite is a soft, lightweight and pale naturally occurring sedimentary rock made up of diatoms. The main component of diatomite is micro-amorphous silica $\left(\mathrm{SiO}_{2} \cdot \mathrm{nH}_{2} \mathrm{O}\right)$ (Alali, 2015; Salman et al., 2016). It is available in abundance in different locations worldwide including the Middle East. Jordan has a substantial source of diatomite $\left(150 \mathrm{Km}^{2}\right)$ where it is located in the Azraq area; $110 \mathrm{~km}$ away from Amman. Jordanian diatomite consists mainly of 41-70.7\% $\mathrm{SiO}_{2}, 10-16 \% \mathrm{Al}_{2} \mathrm{O}_{3}, 2.35-9.9 \% \mathrm{Fe}_{2} \mathrm{O}_{3}, 2-4 \% \mathrm{Na}_{2} \mathrm{O}, 1-$ $2 \% \mathrm{~K}_{2} \mathrm{O}$ and traces of $\mathrm{MgO}, \mathrm{TiO}_{2}, \mathrm{MnO}$ and $\mathrm{P}_{2} \mathrm{O}_{5}$ (Alali, 2015). Different unique and outstanding physicochemical characteristics, such as high surface area, good absorptive capacity, high porosity, chemical inertness, and low density, make diatomite a valuable material and enable it to play an important role in the adsorption process (Alali, 2015; Salman et al., 2016). The existence of an active silanol group distributed over the silica surface which can react with several organic compounds is another advantage for the adsorption process (Khraisheha et al., 2005). Numerous researches showed that diatomite is gaining ground in the adsorption process due to its remarkable efficiency in removing a wide range of pollutants (Salman et al., 2016; Khraisheha et al., 2005; Erdem et al., 2005; Alkan et al.; 2018). The use of Jordanian diatomite for the removal of MG from aqueous solution has not been reported in the literature. Therefore, this paper involves an equilibrium study is part of on-going research that is directed to study the feasibility of using the Jordanian diatomite for the removal of MG dye from textile wastewaters.

\section{Materials and Methods}

\subsection{Adsorbate}

Basic dye namely malachite green (purity $=99 \%$ ) supplied by ACROS organics, USA, was chosen as principal adsorbate and was used without further purification. The chemical formula of $\mathrm{MG}$ is $\mathrm{C}_{23} \mathrm{H}_{25} \mathrm{~N}_{2} \mathrm{Cl}$ (molecular weight=364.92 g/mol). Figure 1 depicts the molecular structure of MG.

\subsection{Solvent}

Deionized water $(18.2 \mu \Omega)$ was the preferred solvent in this work and was used to prepare both the stock MG solutions and reagents.

\subsection{Adsorbent}

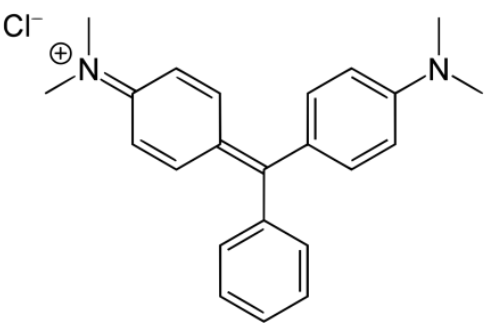

Fig. 1 Molecular structure of malachite green

Due to the superior physicochemical characteristics of diatomite, Jordanian diatomite (surface area $=56.23 \mathrm{~m}^{2} / \mathrm{g}$ ) was chosen as a potential adsorbent for removing MG from aqueous solution. Diatomite was supplied by the Natural Resources Authority, Amman, Jordan. First, diatomite was washed repeatedly with deionized water to eliminate any impurities, dried at $105^{\circ} \mathrm{C}$ overnight under inert condition and desiccated to remove any remaining moisture. Then, it was crushed and sieved to the desired particle sizes. No chemical treatments were applied to the diatomite prior to the batch experiments. Detailed information about the characterization of Jordanian diatomite has been reported elsewhere (Khraisheha et al., 2005; Shawabkeha and Tutunji, 2003; Al-Degs et al., 2000).

\subsection{Equilibrium Adsorption}

A series of batch adsorption experiments have been undertaken to investigate the adsorption efficiency of MG onto Jordanian diatomite under different experimental conditions: $\mathrm{pH}$, initial MG concentration and adsorbent particle size. All other factors are kept constant while carrying out the experiments. An accurately weighed quantity of adsorbent $(0.025 \mathrm{~g})$ of a pre-determined size of diatomite $(500-710 \mu \mathrm{m})$ was added into eight glass sample jars. Stock of MG solution was prepared (1000 ppm) and further diluted accordingly to obtain the desired concentrations within the range $100-900 \mathrm{ppm}$. A $25 \mathrm{ml} \pm 0.5 \mathrm{ml}$ of the MG solution of specific concentration were then added to the glass sample jars. The $\mathrm{pH}$ of $\mathrm{MG}$ solutions was adjusted to the desired value using $0.1 \mathrm{M} \mathrm{HCl} / \mathrm{NaOH}$ solution. Each jar was sealed using parafilm and screwing the top lids. The jars were then placed in a mechanical shaker at 200 rpm for the pre-determined period to reach equilibrium ( 1 week). Upon equilibrium the jars were removed from the shaker, and samples of 4-5ml $\pm 0.5 \mathrm{ml}$ were withdrawn and filtered through $0.45 \mu \mathrm{m}$ cellulose nitrate membrane - after passing enough volume of the dye solution through the filter paper to make sure that no dye is lost and absorbed by the filter paper-, diluted and analysed using Varian Cary-50 UV/VIS spectrophotometer (USA) at $\lambda_{\text {max }}=$ $617 \mathrm{~nm}$. Predetermined standard calibration curves for MG at each $\mathrm{pH}$ were used to measure the residual MG concentration. For particle size and initial MG concentration effects, three different sizes of various meshes $(125-250 \mu \mathrm{m}, 250-500 \mu \mathrm{m}$ and $500-710 \mu \mathrm{m})$ and different initial concentrations (100-900 ppm) were prepared and used. Other parameters like pH, mass of adsorbent and temperature were kept constant. All isotherm adsorption experiments were done in duplicate at room temperature and the mean values were used, as the accepted 
value, in analyzing the data. The removal efficiency of MG and the amount of MG uptake at equilibrium ( $\left.\mathrm{q}_{\mathrm{e}}, \mathrm{mg} / \mathrm{g}\right)$ was calculated using Eq. (1) and Eq. (2), respectively:

Dye removal efficiency $(\%)=\frac{C_{o}-C_{e}}{C_{o}} * 100$

where $C_{o}$ and $C_{e}$ are the initial and equilibrium dye concentration $\left(\mathrm{mg} / \mathrm{dm}^{3}\right)$, respectively, and:

$q_{e}=\frac{\left(C_{o}-C_{e}\right) V}{m}$

where $q_{e}$ is the amount of MG adsorbed at equilibrium $(\mathrm{mg} / \mathrm{g}) ; \mathrm{m}$ is the mass of the diatomite $(\mathrm{g})$ and $V$ is the volume of MG solution $\left(\mathrm{dm}^{3}\right)$.

\section{Results and Discussion 2.1 Adsorption Equilibrium}

Designing any adsorption system is highly depends on adsorption isotherm. Adsorption isotherm is a valuable tool usually used to describe interaction and equilibrium relationships between adsorbent and adsorbate and by which the adsorption capacity of the adsorbent is established (Heydaria and Khavarpour, 2018; Lee et al., 2018). The determination of adsorption isotherm is the first step in evaluating adsorbent performance toward adsorbate (Al-Degs, 2000). Different experimental factors such as pH, initial dye concentration, dose of adsorbent, particle size of adsorbent, contact time and temperature are believed to have great influences on the adsorption efficiency. In this respect, $\mathrm{pH}$, initial concentration of $\mathrm{MG}$ solution and diatomite particle size were adopted as possible candidates influencing the adsorption process in this study.

\subsubsection{Effect of Initial Concentration}

The initial concentration of adsorbate solution plays a fundamental role in the adsorption process. A set of experiments were carried out to study the effect of initial MG on the adsorption process. Different initial MG concentrations $\left(100,300,500,700 \mathrm{and}^{9} 900 \mathrm{mg} / \mathrm{dm}^{3}\right)$ were used. Figure 2 shows the effect of initial MG concentration on the amount of MG adsorbed and on the removal efficiency. The figure reveals that MG uptake has increased with the increase in initial MG concentration. Approximately $88 \%$ increase in MG uptake was observed under the optimum conditions. Increasing initial MG concentration has increased the concentration gradient (driving force) between MG solution and diatomite surface, thus, enhancing MG uptake, which agrees with previously reported results (Pragathiswaran et al., 2016). It is clear that a reduction in the removal efficiency (13\%) has occurred as the initial MG concentration increased from $100-900$ $\left(\mathrm{mg} / \mathrm{dm}^{3}\right)$. This is due to the high competition between MG molecules for the fixed number of available adsorption sites on diatomite surface in the case of higher initial concentration (Heydaria and Khavarpour, 2018). This availability is reduced with the increase in initial MG concentration as most of the adsorption sites became saturated, thus, the removal efficiency was reduced. Therefore, the adsorption process is highly affected by initial MG concentration.

\subsubsection{Effect of pH:}

To ascertain the effect of $\mathrm{pH}$ on the adsorption of MG onto Jordanian diatomite, $\mathrm{MG}$ solution was conditioned to different $\mathrm{pH}$ values covering acidic and alkaline range (3-9). Figure 3 shows the adsorption capacity of $\mathrm{MG}$ as a relationship between the amount of $\mathrm{MG}$ uptake at equilibrium, $q_{e}$, and its final concentration in the aqueous solution, $\mathrm{C}_{\mathrm{e}}$, at different $\mathrm{pH}$ values between 3 and 9 . As seen from the figure, increasing the solution $\mathrm{pH}$ increases the adsorption capacity of $\mathrm{MG}$ onto the Jordanian diatomite. The maximum adsorption capacity attained was $541.1,705.5,730.2$ and $816.2(\mathrm{mg} / \mathrm{g})$ for $\mathrm{pH}$ values of $3,5,7$ and 9 , respectively. MG as a cationic dye occurs in the aqueous solution in the

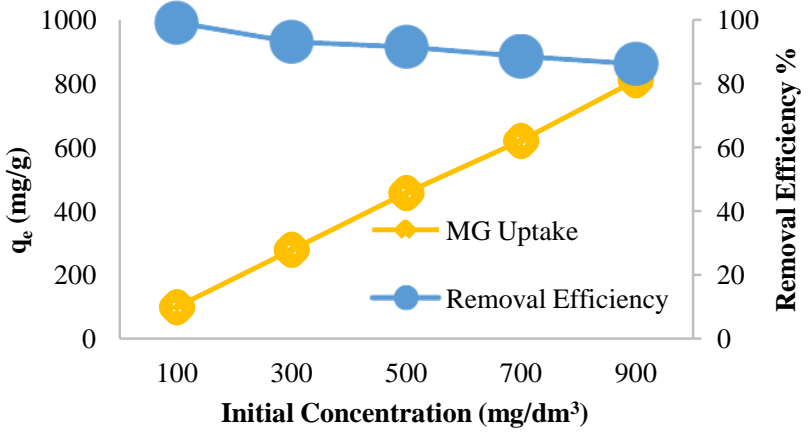

Fig. 2 Effect of the initial dye concentration on the adsorption of MG onto diatomite. Volume of dye solution $=25 \mathrm{~mL}$, mass of adsorbent $=0.025 \mathrm{~g}, \mathrm{pH}=7$, particle size $=250-500 \mu \mathrm{m}$, temperature $=25^{\circ} \mathrm{C}$. form of positively charged ions. Thus, its adsorption onto the adsorbent surface will be governed by the adsorbent surface charge which in turn is affected by the pH of the solution (Lee et al., 2018). Hence, by 
increasing the solution $\mathrm{pH}$, the number of hydroxyl groups, as well as the number of negatively charged sites on the diatomite surface, will be increased and this favors the attraction between MG and diatomite surface (Lai and Chen, 2001). Consequently, Jordanian diatomite operates well in alkali conditions. These results agree well with previously reported results (Ren et al., 2016). The reason for the lower adsorption capacity in the acidic range is attributed to the competition between excess $\mathrm{H}^{+}$ions and the dye cation for the available adsorption sites (Ren et al., 2016). The increase in MG uptake at higher $\mathrm{pH}$ values may also be attributed to two reasons: the dimerization of MG or the reaction of MG with sodium hydroxide (Shawabkeha, and Tutunji, 2003). According to Felix (2017), the reaction of MG with sodium hydroxide causes fading of MG. The author attributes the fading to the attack of $\mathrm{OH}^{-}$on the central $\mathrm{C}$ atom of the planar ring system of MG.

The effect of solution $\mathrm{pH}$ can also be described based on the zero point of charge $\left(\mathrm{pH}_{\mathrm{ZPC}}\right)$ which is an indication of the ability of the adsorbent surface to become protonated (positively charged) or deprotonated (negatively charged). Jordanian's $\mathrm{pH}_{\mathrm{ZPC}}$ diatomite was determined and found to be around 5.4. When the $\mathrm{pH}$ of the solution is $<\mathrm{pH}$ versa (Benmaamar et al., 2016). Therefore, in the alkaline range, the $\mathrm{pH}$ of the solution is $>\mathrm{pH}_{\mathrm{ZPC}}$ and the diatomite acts as a negative surface and enhances the uptake of the positively charged dye (MG). Diatomite shows 16.7-98.9\% of MG removal over the whole concentration range (100-900 ppm).

\subsubsection{Effect of Particle Size}

The particle size is another important factor that affects the adsorption process. To explore the impact of diatomite particle size on the adsorption capacity of MG, multiple adsorption tests were conducted with three different particle sizes namely, $125-250 \mu \mathrm{m}, 250-500 \mu \mathrm{m}$ and $500-710 \mu \mathrm{m}$, where all other factors were kept constant, and the results are shown in Figure 4. It is clear from the figure that an inverse relationship exists between diatomite particle size and diatomite adsorption capacity. With the initial MG concentration of $700\left(\mathrm{mg} / \mathrm{dm}^{3}\right)$, MG uptake has increased from $588.9(\mathrm{mg} / \mathrm{g})$ to $659(\mathrm{mg} / \mathrm{g})$ as the particle size decreases from 500 $710 \mu \mathrm{m}$ to size $125-250 \mu \mathrm{m}$. This can be explained by the fact that on decreasing the particle size, more surface area is available for the adsorption of MG (Erdem et al., 2005, Joseph et al., 2013). The removal efficiency of MG dropped from 92.1 to $81.1 \%$ with increasing particle size from $125-250 \mu \mathrm{m}$ to $500-710 \mu \mathrm{m}$. Thus, smaller particle size is favorable for the adsorption of MG onto Jordanian diatomite.

\subsection{Adsorption Isotherm Modelling}

Equilibrium isotherm models can provide substantial information regarding the capacity of adsorbent, interaction between an adsorbent and adsorbate, surface properties and affinity of the adsorbent and sorption mechanism that can be used for designing the adsorption process (Lee et al., 2018; Sawasdee and Watcharabundit, 2015). Thus, best-fit isotherm is essential. According to Lee et al. (2018) fitting the experimental data to different isotherm models is helpful in indicating the most appropriate model to be used in the design of the adsorption system.

Experimental data were analyzed according to the linear form of Langmuir, Freundlich, Temkin, Flory-Huggins, Halsey, and Jovanovic isotherm models and plots were constructed. Table 1 displays the results of the calculated isotherm constants at $\mathrm{pH}=7$. Langmuir plots gave nonlinear relationships between $C_{e} / q_{e}$ and $C_{e}$ which indicates the inability of the model to simulate the experimental data. However, the experimental data were well fitted with the Freundlich model and this might indicate the heterogeneous distribution of the active sites and

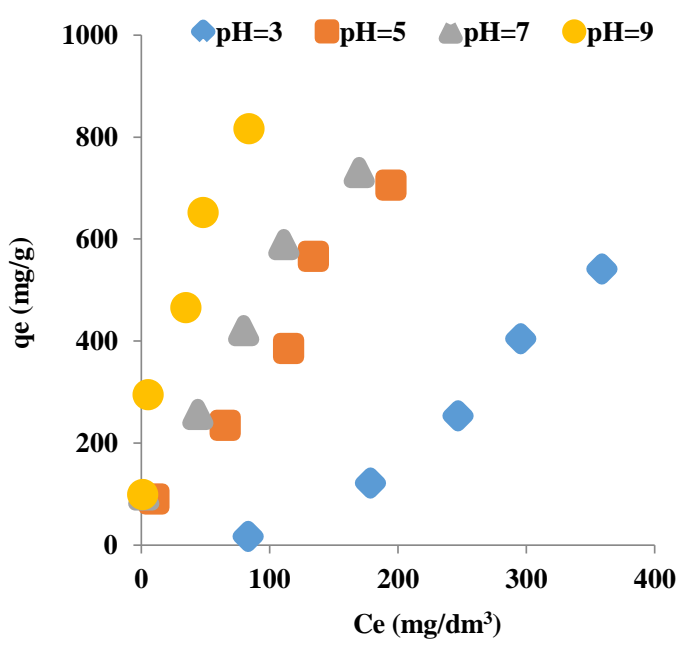

Fig. 3 Effect of the solution $\mathrm{pH}$ on the adsorption of MG onto diatomite. Volume of dye solution $=25 \mathrm{~mL}$, mass of adsorbent $=0.025 \mathrm{~g}$, concentration $=100-900 \mathrm{mg} / \mathrm{dm}^{3}$, particle size $=500-710 \mu \mathrm{m}$, temperature $=25^{\circ} \mathrm{C}$.

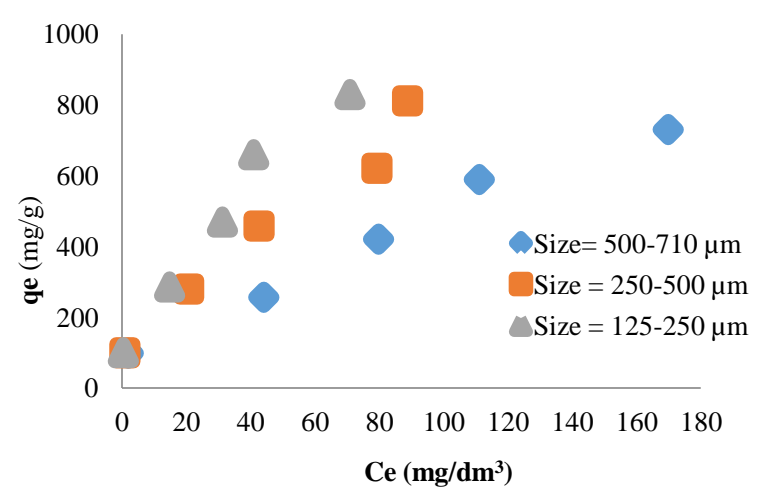

Fig.4 Effect of adsorbent particle size on the adsorption of MG onto diatomite. Volume of dye solution $=25 \mathrm{ml}$, mass of adsorbent $=0.025 \mathrm{~g}, \quad$ concentration $=100-900 \mathrm{mg} / \mathrm{dm}^{3}, \quad \mathrm{pH}=7$, temperature $=25^{\circ} \mathrm{C}$. 
multilayer adsorption. The Temkin model showed poor representation of the experimental data. The inability of the Temkin isotherm model to simulate the experimental MG data very well may suggest the nonuniform surface morphology of diatomite (Amin et al., 2017). Moreover, it may indicate that the sorbate-adsorbate interactions do not exist. Adsorption energy, $\Delta \mathrm{Q}=(-\Delta \mathrm{H})$, is positive for all studied conditions, indicating the exothermic nature of the adsorption process of MG onto diatomite (Hamdaouia and Naffrechoux, 2007). According to Amin et al. (2015), Temkin model is not appropriate for predicting the equilibrium in the complex liquid-phase adsorption systems. The values of the standard Gibbs free energy calculated from the Flory-Huggins model were negative for all the studied conditions, referring to the spontaneity of the adsorption of MG onto Jordanian diatomite and supports an exothermic nature (Theivarasu and Mylsamy, 2011). It is noticeable from Table 1 that the experimental results obtained for MG shows compatible trends with Halsey isotherm. Halsey model supports the Freundlich model and affirms the fact that the adsorption process of MG onto Jordanian diatomite is of a multilayered nature and confirms the heterogeneous nature of diatomite. Sampranpiboon et al. (2014) declared that the ability of the Halsey model to fit the experimental data attest to the heterosporous nature of adsorbent. Jovanovic model could not describe the experimental data. This emphasizes that the adsorption of MG onto Jordanian diatomite favors multilayer coverage and again support the assumptions of the Freundlich model. In addition, Table 1 reveals that the correlation coefficient, $\boldsymbol{r}^{2}$, for Langmuir model is the lowest. Low values of $\boldsymbol{r}^{2}$ indicate the inconsistency of the Langmuir model to fit the experimental data. This was expected since the experimental isotherms obtained did not present the typical Langmuirian form. The correlation coefficient for the Freundlich model was comparatively the highest suggesting the applicability of the Freundlich model to describe the MG-diatomite adsorption process.

Table 1 Isotherm constants for MG-diatomite system at $\mathrm{pH}=7$ and particle size $=500-710 \mu \mathrm{m}$.

\begin{tabular}{|c|c|c|c|c|c|c|}
\hline $\begin{array}{c}\text { Model } \\
\text { (Reference) }\end{array}$ & Linear Form & & & Constants & & $\mathbf{r}^{2}$ \\
\hline $\begin{array}{c}\text { Langmuir } \\
\text { (Sampranpiboon } \text { et al., 2014) }\end{array}$ & $\frac{C_{e}}{q_{e}}=\frac{1}{K_{L}}+\frac{a_{L}}{K_{L}} C_{e}$ & $\begin{array}{c}\mathrm{k}_{\mathrm{L}} \\
\left(\mathrm{dm}^{3} / \mathrm{g}\right)\end{array}$ & 14.08 & $\mathrm{R}_{\mathrm{L}}$ & 0.073 & 0.729 \\
\hline $\begin{array}{c}\text { Freundlich } \\
\text { (Yang et al., 2017) }\end{array}$ & $L n q_{e}=L n K_{F}+\frac{1}{n} L n C_{e}$ & $\begin{array}{c}\mathrm{k}_{\mathrm{f}} \\
\left(\mathrm{mg} / \mathrm{g} \cdot\left(\mathrm{mg} / \mathrm{dm}^{3}\right)^{1 / \mathrm{n}}\right)\end{array}$ & 67.76 & $\mathrm{n}$ & 2.320 & 0.941 \\
\hline $\begin{array}{c}\text { Temkin } \\
\text { (Hamdaouia and Naffrechoux, 2007) }\end{array}$ & $\theta=\frac{R T}{\Delta Q} \operatorname{Ln} K_{T}+\frac{R T}{\Delta Q} \operatorname{Ln} C_{\epsilon}$ & $\begin{array}{c}\mathrm{K}_{\mathrm{T}} \\
\left(\mathrm{dm}^{3} / \mathrm{mg}\right)\end{array}$ & 0.772 & $\begin{array}{c}\Delta \mathrm{Q} \\
(\mathrm{kJ} / \mathrm{mol})\end{array}$ & 25.63 & 0.764 \\
\hline $\begin{array}{c}\text { Flory-Huggins } \\
\text { (Theivarasu and Mylsamy, 2001) }\end{array}$ & $\operatorname{Ln}\left(\frac{\theta}{C_{0}}\right)=\operatorname{Ln} K_{F H}+n \ln (1-\theta)$ & $\begin{array}{c}\mathrm{K}_{\mathrm{FH}} \\
\left(\mathrm{dm}^{3} / \mathrm{mol}\right)\end{array}$ & $2.90 * 10^{-4}$ & $\mathrm{n}$ & -0.900 & 0.885 \\
\hline $\begin{array}{c}\text { Halsey } \\
\text { (Amin } \text { et al., 2015) }\end{array}$ & $\operatorname{Ln} q_{e}=\frac{1}{n_{H}} \operatorname{Ln} K_{H}-\frac{1}{n_{H}} \operatorname{Ln} C_{e}$ & $\underset{\left(\mathrm{mg} / \mathrm{dm}^{3}\right)}{\mathrm{K}_{\mathrm{H}}}$ & $5.73 * 10^{-5}$ & $\mathrm{n}$ & -2.315 & 0.941 \\
\hline $\begin{array}{c}\text { Jovanovic } \\
\text { (Sampranpiboon } \text { et al., 2014) }\end{array}$ & $L n q_{e}=L n q_{\max }-K_{J} C_{e}$ & $\begin{array}{c}\mathrm{K}_{\mathrm{J}} \\
\left(\mathrm{dm}^{3} / \mathrm{g}\right)\end{array}$ & -0.012 & $\begin{array}{c}\mathrm{q}_{\max } \\
(\mathrm{mg} / \mathrm{g})\end{array}$ & 130 & 0.803 \\
\hline
\end{tabular}

Since modeling results manifest that the Freundlich isotherm model is the best one to simulate the adsorption of MG onto diatomite, discussion will be focused more on this model. Table 2 displays the results of the calculated Freundlich isotherm constants at different $\mathrm{pH}$ values. The results also show that the value of $\mathrm{n}$ is greater than unity indicating that the MG is favourably adsorbed by diatomite. Yildiz (2017) announced that $\mathrm{n}$ value greater than 1 indicates spontaneous adsorption conditions. An increase in $K_{f}$ values was observed which indicates that adsorption affinity increases with increasing solution $\mathrm{pH}$. This trend may indicate multilayer adsorption. The magnitude of the Freundlich constant indicates easy uptake of MG from aqueous solution. This is in great agreement with the previous findings regarding $\mathrm{pH}$ effect on the adsorption of MG. According to Arivoli et al. (2009) physisorption is much more favorable when n is less than one. Heydaria and Khavarpour (2018) reported that a higher value of $K_{f}$ is an indication of a higher affinity of adsorbent toward adsorbate. Figure 5 displays a theoretical plot of Freundlich isotherm with the experimental data for the adsorption of MG onto diatomite at $\mathrm{pH}=3$. It is obvious from the figure that the experimental data are best fitted with Freundlich isotherm. Table 3 lists the results of the calculated Freundlich isotherm constants at different particle sizes for MG-diatomite systems. As seen from the table, the Freundlich model again represents the experimental data very well. The values of the correlation coefficient, $\boldsymbol{r}^{2}$, for Freundlich model support this finding. It is also evident that the affinity of the adsorbents decreases as the particle size increases. This confirms that MG uptake was a function of the external surface area of the adsorbent. This is consistent with the previous results obtained.
Table 2 Freundlich isotherm constants for the diatomiteMG system at different $\mathrm{pH}$ values.

\begin{tabular}{lccc} 
pH & \multicolumn{3}{c}{ Freundlich Constants } \\
& $\begin{array}{c}\boldsymbol{k}_{f} \\
\left(\mathbf{m g} / \mathbf{g} .\left(\mathbf{m g} / \mathbf{d m}^{\mathbf{3}}\right)^{\mathbf{1 / n}}\right)\end{array}$ & $\mathbf{n}$ & $\mathbf{r}^{\mathbf{2}}$ \\
\hline 3 & 1.012 & 1.013 & 0.996 \\
5 & 17.49 & 1.475 & 0.995 \\
7 & 67.76 & 2.320 & 0.941 \\
9 & 108.6 & 2.200 & 0.964
\end{tabular}




\subsection{Error Analysis}

Error function namely, the Average Relative Error Deviation (ARED) and Chi-square test $\left(\chi^{2}\right)$ were used to evaluate the fit of the isotherm equations to the experimental data and determine the best- fitting equation. The expression of these error functions are given in Eq. (3) and Eq. (4) (Benmaamar et al., 2016; Kooh et al., 2016):

$$
A R E D=\frac{100}{n} \sum_{i=1}^{n}\left|\frac{q_{e, \exp }-q_{e, \text { calc }}}{q_{e, \exp }}\right|_{i}
$$

and

$$
\text { Chi-squareTest }\left(\chi^{2}\right)=\sum_{i=1}^{n} \frac{\left(q_{e, \exp }-q_{e, \text { calc }}\right)^{2}}{q_{e, \exp }}
$$

Table 3 Freundlich isotherm constants for the diatomite-MG system at different particle sizes.

\begin{tabular}{lccc}
\hline $\begin{array}{l}\text { Size } \\
(\boldsymbol{\mu m})\end{array}$ & $\begin{array}{c}\boldsymbol{k}_{f} \\
\left(\mathbf{m g} / \mathbf{g} \cdot\left(\mathbf{m g} / \mathbf{d m}^{3}\right)^{1 / \mathbf{n}}\right)\end{array}$ & $\mathbf{n}$ & $\boldsymbol{r}^{2}$ \\
\hline $125-250$ & 133.5 & 2.557 & 0.947 \\
$250-500$ & 97.72 & 2.358 & 0.959 \\
$500-710$ & 67.76 & 2.320 & 0.941 \\
\hline
\end{tabular}

Where $q_{e, \text { exp }}$ is the experimental value, $q_{e, \text { calc }}$ is the calculated value and $\mathrm{n}$ is the number of data points in the experiment. The results of these statistical tools showed that the Chi-square test value and ARED value of Freundlich is the smallest. This indicates that the calculated value of $q_{e}$ using Freundlich model is closer to $q_{e}$ obtained experimentally. This is consistent with the previous results and manifests the earlier findings that the experimental data are best fitted with Freundlich isotherm. Table 4 summarizes the results for the adsorption of $\mathrm{MG}$ onto diatomite at $\mathrm{pH}=9$.

\section{Conclusions}

4 Error deviation data for the adsorption of MG onto

\begin{tabular}{|c|c|c|}
\hline Error Function & ARED & $\chi^{2}$ \\
\hline Langmuir & 21.73 & 92.22 \\
\hline Freundlich & 11.14 & 28.91 \\
\hline Temkin & 15.35 & 55.23 \\
\hline Halsey & 11.32 & 29.12 \\
\hline Jovanovic & 86.74 & 163.5 \\
\hline
\end{tabular}
diatomite at $\mathrm{pH}=9$.

The focus of this research was to investigate the potential use of Jordanian diatomite as an adsorbent for the removal of malachite green dye (MG) from aqueous solution. The results indicated the major role played by the $\mathrm{pH}$ of $\mathrm{MG}$ solution. The optimum $\mathrm{pH}$ value for the removal of $\mathrm{MG}$ was $=9$. Diatomite particle size showed a vital effect on the adsorption capacity of diatomite and it can be concluded that smaller diatomite particles are recommended for the removal of $\mathrm{MG}$ from aqueous solution. Initial MG concentration proved to play an essential role in the adsorption process, the lower the initial dye concentration, the faster the MG removal. Freundlich isotherm was able to simulate the equilibrium data very well. Based on these mentioned results, Jordanian diatomite could potentially be used as a low-cost promising adsorbent for treating MG effluents.

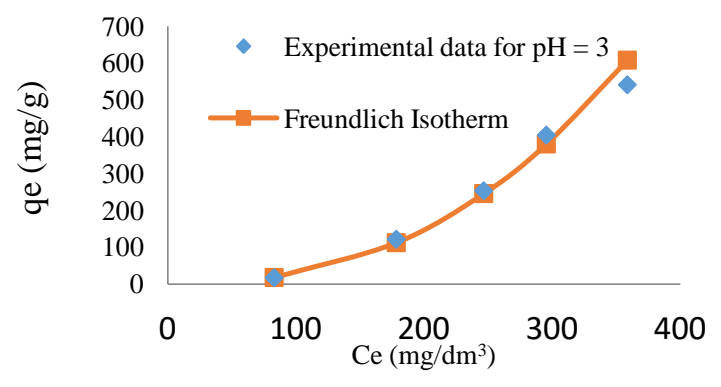

Fig. 5 Model fit of adsorption isotherm of MG adsorption onto diatomite

\section{Nomenclature}

$\begin{array}{lll}\mathrm{a}_{\mathrm{L}} & \text { =Langmuir constant } & {[\mathrm{dm} / \mathrm{mg}]} \\ \mathrm{C}_{\mathrm{e}} & =\text { Equilibrium dye concentration } & {\left[\mathrm{mg} / \mathrm{dm}^{3}\right]} \\ \mathrm{C}_{\mathrm{o}} & \text { =Initial dye concentration } & {\left[\mathrm{mg} / \mathrm{dm}^{3}\right]} \\ \mathrm{K}_{\mathrm{F}} & =\text { Freundlich constant } & {\left[\mathrm{mg} / \mathrm{g} \cdot\left(\mathrm{mg} / \mathrm{dm}^{3}\right)^{1 / \mathrm{n}}\right]} \\ K_{\mathrm{FH}} & =\text { Equilibrium constant } & {[\mathrm{dm} / \mathrm{mol}]} \\ \mathrm{K}_{\mathrm{H}} & =\text { Halsey isotherm constant } & {\left[\mathrm{mg} / \mathrm{dm}^{3}\right]} \\ \mathrm{K}_{\mathrm{L}} & =\text { Langmuir constant } & {\left[\mathrm{dm}^{3} / \mathrm{g}\right]} \\ \mathrm{K}_{\mathrm{J}} & =\text { Jovanovic constant } & {\left[\mathrm{dm}^{3} / \mathrm{g}\right]} \\ \mathrm{K}_{\mathrm{T}} & =\text { Equilibrium binding constant } & {\left[\mathrm{dm}^{3} / \mathrm{mg}\right]} \\ \mathrm{m} & \text { =Mass of the diatomite } & {[\mathrm{g}]} \\ \mathrm{n} & =\text { Heterogeneity factor } & {[-]} \\ \mathrm{n}_{\mathrm{H}} & =\text { Halsey isotherm constant } & {[-]} \\ \Delta \mathrm{Q} & =\text { Variation of adsorption energy } & {[\mathrm{J} / \mathrm{mol}]} \\ \mathrm{q}_{\mathrm{e}} & =\text { Amount of MG adsorbed at equilibrium } & {[\mathrm{mg} / \mathrm{g}]} \\ \mathrm{q}_{\mathrm{e}, \text { calc }} & =\text { Calculated value } & {[\mathrm{mg} / \mathrm{g}]}\end{array}$




$\begin{array}{lll}\mathrm{q}_{\mathrm{e}, \exp } & =\text { Experimental value } & {[\mathrm{mg} / \mathrm{g}]} \\ \mathrm{q}_{\max } & =\text { Maximum uptake of adsorbate } & {[\mathrm{mg} / \mathrm{g}]} \\ \mathrm{R} & =\text { Universal gas constant } & {[\mathrm{J} / \mathrm{mol} . \mathrm{K}]} \\ \mathrm{T} & =\text { Absolute temperature } & {[\mathrm{K}]} \\ \mathrm{V} & =\text { Volume of MG solution } & {\left[\mathrm{dm}^{3}\right]} \\ \theta & =\text { Fractional coverage } & {[-]}\end{array}$

\section{References}

Alali, J., Diatomite, Ministry of Energy and Mineral Resources, Jordan (2015).

Al-Degs, Y. S. Adsorption of Anionic Reactive Dyes on Activated Carbon from Aqueous Solution [dissertation]. Queen's University Balfast. 2000.

Al-Degs, Y., Tutunji M, and Shawabkeha R., "The Feasibility of Using Diatomite and Mn-Diatomite for Remediation of $\mathrm{Pb}^{2+}, \mathrm{Cu}^{2+}$, and $\mathrm{Cd}^{2+}$ from Water", Sep. Sci. \& Tech., 35, 2299-2310 (2000).

Al-Wahbi, A., "Adsorption of Diazo Dye C.I. Acid Red 97 from Aqueous Solution onto Yemen Natural Clay: Equilibrium and Thermodynamic Studies", Jordanian J. of Eng. Chem. Indus. (JECI), 1, 1-11 (2018).

Ali, I., Peng C., Yeac T., and Naz, I. "Sorption of Cationic Malachite Green Dye on Phytogenic Magnetic Nanoparticles Functionalized by 3-Marcaptopropanic Acid", Royal Soci. Chem. Adv., 8, 8878-8897 (2018).

Alkan, S., Çalişkan M., Irende I., and Kul A., "Adsorption Equilibrium and Thermodynamics of Diatomite (Çaldiran/Van) On Some Textile Dyes”, J. Chem. Soc. Pakistan, 40, 457-466 (2018).

Amin, M., Alazba A., and Shafiq M., "Adsorptive Removal of Reactive Black 5 from Wastewater Using Bentonite Clay: Isotherms, Kinetics and Thermodynamics", Sustainability, 7, 15302-15318 (2015).

Amin, M., A. Alazba A., and Shafiq M., "Non-Spontaneous and Multilayer Adsorption of Malachite Green Dye by Acacia Nilotica Waste with Dominance of Physisorption", Water Sci. and Tech., 76, 1805-1815 (2017).

Arivoli, S., Hema M., and M. Prasath P., "Adsorption of Malachite Green onto Carbon Prepared from Borassus Bark", The Arabian J. Sci, Eng., 34, 31-42 (2009).

Benmaamar, Z., H. Boutoumi, H. Hamitouche, H. Benmaamar, S. Mazari, A. Benmaamar and A. Aggoun, "Simulation of Adsorption Kinetics of Malachite Green onto Coffee Residues", Revue Science des Matériaux, Laboratoire, 8, 1-11 (2016).

Blanco-Flores, A., Gutiérrez-Segura E., Sánchez-Mendieta V., and Vilchis-Néstor, A. "Removal of Malachite Green Dye from Aqueous Solution Through Inexpensive and Easily Available Tuffite, Bentonite and Vitreous Tuff Minerals", Revista Latinoamericana de Recursos Naturales, 12, 1-17 (2016).

Chowdhury, S. and Saha, D. "Adsorption of Malachite Green from Aqueous Solution by NaOH-Modified Rice Husk: Fixed-Bed Column Studies", Envi. Prog. and Sust. Energy, 32, 633-639 (2013).

Dhahir, S. A., Abdul-Hussein E., Sarhan S., and Faraj N., "Adsorption of Malachite Green Dye From Aqueous Solution onto Iraqi Raw Al-Hussainiyat Clay", Eur. Chem. Bull., 2, 866-872 (2013).

Erdem, E., Çölgeçen G., and Donat R., “The Removal of Textile Dyes by Diatomite Earth”, J. Collo. and Interf. Sci., 282, 314-319 (2005).

Felix, L., "Kinetics of the Reaction between Malachite Green and Hydroxyl Ion in the Presence of Reducing Sugars", J. Chem. Tech. and Metal., 52, 526-531 (2017).

Gajare, S. M. and Menghani, S. "Biosorption of Malachite Green by Naturally Grown Algal Biomass from Girna River, Jalgaon District, Maharashtra", J. Algal Biomass Utln., 3, 60-65 (2012).

Hamdaouia, O. and Naffrechoux, E. "Modeling of Adsorption Isotherms of Phenol and Chlorophenols onto Granular Activated Carbon Part I. Two-Parameter Models and Equations Allowing Determination of Thermodynamic Parameters", J. Haz. Mat., 147, 381-394 (2007).

Heydaria, R. and Khavarpour, M. "Adsorption of Malachite Green from Aqueous Solution by Nanozeolite Clinoptilolite: Equilibrium, Kinetic and Thermodynamic Studies", Int. J. Eng., 31, 1-11 (2018).

Joseph, F., Agrawal Y., and Rawtani, D. "Behavior of Malachite Green with Different Adsorption Matrices", Frontiers in Life Sci., 7, 99-111 (2013).

Khraisheha, M., A. Al-Ghouti M., Allen S., and Ahmad, M. "Effect of OH and Silanol Groups in the Removal of Dyes from Aqueous Solution Using Diatomite", Water Res., 39, 922-932 (2005).

Kooh, M., Dahri M., M. and Lim, L. "The Removal of Rhodamine B Dye from Aqueous Solution Using Casuarina Equisetifolia Needles as Adsorbent" Cogent Envi. Sci., 2, 1-14 (2016)

Lai, C. H. and C. Y. Chen, "Removal of Metal Ions and Humic Acid from Water by Iron-Coated Filter Media", Chemosphere, 44, 1177-1184 (2001).

Lee, Y., Amini M., Sulaiman N., Mazlan M., and Boon, J. "Batch Adsorption and Isothermic Studies of Malachite Green Dye Adsorption Using Leucaena Leucocephala Biomass as Potential Adsorbent in Water Treatment”, Songklanakarin J. Sci. Technol., 40, 563-569 (2018).

Litefti, K., Freire, M., Stitou M., and González-Álvarez J. "Biosorption of cationic textile dyes by a forest industry residue: Pinus pinaster bark", $15^{\text {th }}$ International Conference on Environmental Science and Technology, Greece: 2017.

Oktay, B., Elevli S., and Coruh, S. "Malachite Green Dye Removal Using Montmorillonite Clay: Full Factorial Design Analysis", Int. J. Adv. Sci. Eng. Tech., 4, 1317 (2016).

Pan, X. and Zhang, D. "Removal of Malachite Green from Water by Firmiana Simplex Wood Fiber", Elect. J. Biotech., 12, 4-14 (2009).

Pragathiswaran, C., Krishnan N., Abbubakkar, B., Govindhan P., and Abuthahir K., "Adsorption of Malachite Green Dye onto Activated Carbon Obtained from the Gloriosa Superba Stem", Int. J. Res. Phar. Chem., 6, 57-61 (2016).

Ren, Z., Guan, J., Gao, H., Tian, J., Wen Y., and Zheng, R. "Characteristics of Cationic Red X-Grl Adsorption by Raw Diatomite and Diatomite Concentrate", Physicochem. Probl. Miner. Process, 52, 44-55 (2016).

Roja, K., Ramesh N., and Ramesh. S., Adsorption Studies for the Removal of Malachite Green Dye from Aqueous Solution Using Graphene Oxide. International Conference on Recent Trends in Environmental Science and Engineering, India: 2017

Salman, T., Temel, F., Turan N., and Ardali, Y. "Adsorption of Lead (Ii) Ions onto Diatomite from Aqueous Solutions: Mechanism, Isotherm and Kinetic Studies", Global NEST J., 18, 1-10 (2016).

Sampranpiboon, P., Charnkeitkong P., and Feng, X. "Equilibrium Isotherm Models for Adsorption of Zinc (II) ion from Aqueous Solution on Pulp Waste", Wseas Trans. on Envir. Devel., 10, 35-47 (2014).

Sartape, A., M. Mandhare, A., Jadhav, V., Raut, P., Anuse M., and Kolekar, S. "Removal of Malachite Green Dye from Aqueous Solution with Adsorption Technique Using Limonia Acidissima (Wood Apple) Shell as Low Cost Adsorbent”, Arabian J. chem.,10, S3229-S3238 (2017).

Sawasdee, S. and Watcharabundit, P. "Equilibrium, Kinetics and Thermodynamic of Dye Adsorption by Low-Cost Adsorbents", Int. J. Chem. Eng. Appl., 6, 444-449 (2015).

Shawabkeha, R., and Tutunji, M. “Experimental study and modeling of basic dye sorption by diatomaceous clay”, App. Clay Sci., 24, 111-120 (2003) 
Theivarasu, C., and Mylsamy, S. "Removal of Malachite Green from Aqueous Solution by Activated Carbon Developed from Cocoa (Theobroma Cacao) Shell - A Kinetic and Equilibrium Studies", E-J. Chem., 8, S363-S371 (2011).

Tian, L., Zhang, J., Shi, H., Li N., and Ping, O. "Adsorption of Malachite Green by Diatomite: Equilibrium Isotherms and Kinetics Studies", J. Disp. Sci. Tech., 37, 1059-1066 (2016).

Yang, X., Zhang, Y., Wang, L., Cao, L., Li. K., and Hursthouse, A. "Preparation of a Thermally Modified Diatomite and a Removal Mechanism for 1-Naphthol from Solution", Water, 9, 651-665 (2017).

Yildiz, S., "Kinetic and Isotherm Analysis of Cu(Ii) Adsorption onto Almond Shell (Prunus Dulcis)", Ecol. Chem. Eng. S, 24, 87-106 (2017). 